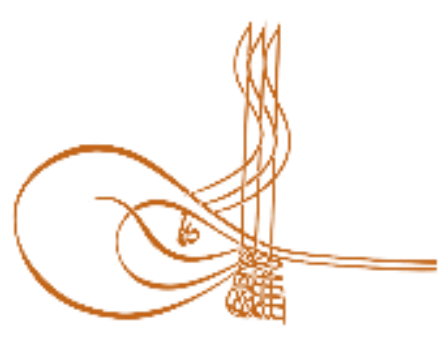

www.turkishstudies.net/social
Turkish Studies - Social Sciences

eISSN: $2667-5617$

Research Article / Araștırma Makalesi

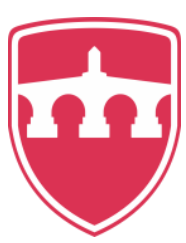

INTERNATIONAL

BALKAN

UNIVERSITY

Sponsored by IBU

\title{
I. Kant'ın Ödev Ahlakı ve j. S. Mill'in Faydacılık Kuramı Bağlamında Basında Etik Kod Belirlemenin Gerekliliği ve Küreselleşmenin Etkisi
}

\author{
Necessity to Define Ethical Codes for the Media and the Impact of Globalization within the Context \\ of I. Kant's Ethics of Duty and J. S. Mill's Utilitarianism
}

\author{
Çiğdem Tosun*
}

\begin{abstract}
The position of the media on the axis of politics and economy as the fourth estate, the transformation of technology in the realm of media and the issue of control as a result of the change of ownership structure in the media have led to discussions on the functions of the media and the codes of conduct for journalists, and brought the press ethics into question. In terms of journalism ethics, Kantian ethics of duty and Mill's utilitarianism have been included in this study. The aim of the study is to base the necessity of ethical codes in the press in the context of the ethical views of two important thinkers. Kant dwells on the universality of subjective principles, which we adopt in our actions, and proposes that such principles of action, which might be safely be made a law for the whole world, should be indicative of the decisions for our actions. Mill, however, formulates the value of actions with the concept of utility. Mill expresses that achieving social happiness is the basic principle in ethical actions. Both approaches deal with the principles in evaluating actions. There is a consensus on the necessity for ethical codes. Nevertheless, the necessity for evaluating each case on its own requires pre-defined guiding principles. The necessity for defining ethical codes might as well be used to create grounds to justify the interests of the global hegemons, thus unethical behaviors become acceptable. With the global impact in the "New World Order," ethical codes entail the risk of being abused by the powers, that wish to hold on to their hegemony, under the disguise of offering a solution to the ethical issues. In this study, the necessity of ethical codes in the press is based on the ethical views of two thinkers. It is revealed that ethical codes will be a guide for journalists and the free will of the journalist will be decisive in assessing the uniqueness of each ethical situation. In this study, source scanning method has been used as data collection technique.
\end{abstract}

Structured Abstract: Ethics is a field where actions are evaluated as good and bad in the context of responsibility and virtue, and where the worthiness of the action is determined according to the underlying principles. Ethical codes determined in the field of ethics are a set of principles applied in order to make a decision before the action and to make an evaluation after it in terms of worthiness and truthfulness. While

*Dr.
PhD.

ORCID 0000-0001-9305-1453

cigdemtosun865@gmail.com

Cite as/ Atıf: Tosun, Ç. (2020). I. Kant'ın ödev ahlakı ve j. S. Mill'in faydacılık kuramı bağlamında basında etik kod

belirlemenin gerekliliği ve küreselleşmenin etkisi, Turkish Studies - Social, 15(1), 699-714.

https://dx.doi.org/10.29228/TurkishStudies.37346

Received/Geliş: 18 September/Eylül 2019

Accepted/Kabul: 25 February/Şubat 2020

Checked by plagiarism software

Copyright $($ INTAC LTD, Turkey 
the concept of 'good' is fundamentally included in the ethical field, the fact that actions are 'right' and 'valuable' also affects the desirability of the behavior. Since the necessity of evaluating each event as being unique makes a formula ready for the solution insufficient, the solution of ethical problems becomes the main problem. The boundaries of the field of ethics are set by problems which law does not address. Behaving according to the codes of ethics is achieved not through an obligations like legal sanctions, but through a requirement of conscience and a requirement determined in the context of social rules.

When it comes to press ethics, the elements such as politics, economics, technology, changing ownership structure diversify ethical problems and make it difficult to come up with solutions. The media is no longer behind as the fourth power under the circumstances that have changed over time, but plays an even more prominent role in shaping the public opinion in the desired way through the striking impact of the economy on the media. The effect of the decisive role of the economy has also made the media a priority over other elements. The phenomenon of ownership in the media undermines the concepts of neutrality and independence on the impact of the economy. Therefore, press ethics is an issue that needs to be more focused on. A media whose control mechanisms are not functioning also carries the danger of legitimizing an unethical situation with an intrusive and manipulative function under the name of social benefit. The media's contribution to the formation of public opinion and its control function began to become dysfunctional as the position of the media within the social system became dependent on the political and economic power focuses and the transformation of the media. As a result of journalists being forced to make news in line with the interests of the institution in which they worked, their encounters with situations where press ethics are disregarded have also been effective in this process.

There are different approaches to press ethics. Kant mentions the concept of maxim, the subjective principle of will, and states that this principle should be valid for everyone. Kant describes freedom as the ability to make independent decisions and will. On the other hand, Mill's viewpoint is based on providing the well-being of the greatest number of people. Mill, who sees the good as the beneficial, describes the value of action with the concept of benefit. Mill accepts actions that give happiness as valuable. When it comes to ethics, making decisions according to the quantitative does not always bring about the correct results. Even if the results are correct, the 'worthiness' of the action can be the subject of discussion. Therefore, it is more guiding to take a subjective principle that will be considered valid by everyone as a starting point and define individual decision making as freedom in the field of ethics.

While mentioning the social effect in the determination of ethical codes, the principles to be determined universally are also emphasized. While the code of ethics is a guide for media professionals in a society that enables them to act responsibly and make decisions with their free will, it also has the disadvantage of being a tool used by powers who want to establish and maintain their domination in the global arena. The principles determined at the global level make the unilateral flow of information the norm and legitimate the existence of a single authority. The fact that the press gives the news impartially is one of the principles determined at the global level. In the news reported, there is no clarity about the criteria according to which the news will be conveyed in case of conflicts of national and international interests. Since the transfer of information by the powerful is faster and more effective, unilateral information flow emerges as an ethical problem. Ethical codes determined by the global influence can become a tool for international media organizations to reproduce their sovereignty. This makes the stages of identifying and implementing ethical codes even more important.

The function of integrating ethical codes becomes the means of directing the masses in the hands of the powers that use ethical codes for their own purposes and this dangerous process operates invisibly as they apply it in an implicit and legitimizing way. That the institutions in the media create their own code of professional ethics is a continuation of this process. While one is prevented from working independently from the media firm, one is made to comply with the ethical codes devised by the firm, which results in contradiction. This contradictory structure conceals that it restricts freedom of the press by over-idealizing ethical codes. Ethical codes have not only become dysfunctional in serving the ethical field but also very effective in maintaining the domination of sovereign powers.

Since ethical codes determine what the journalist should do when confronted with situations that he or she will decide individually, it is his or her conscience that will judge the subjective decision that the individual will make. In the field of media, the journalist is guided by the ethical code which is a requirement during the decision-making process when faced with the events. In order for this requirement not

Turkish Studies - Social, 15(1) 
to become an instrument of interest groups, ethical codes that will be acceptable by everyone should be determined and journalists should be free in the decision-making process.

Keywords: Press, ethics, globalization, ethics of duty, utilitarianism.

Öz: Dördüncü güç olarak nitelendirilen medyanın siyaset ve ekonomi eksenindeki konumu, teknolojinin medya alanını dönüşüme uğratması, medyada mülkiyet yapısının değişmesi sonucu karşılaşılan kontrol sorunu medyanın işlevlerinin ve gazetecilerin davranış kodlarının tartışılmasına neden olmuş ve basın etiğini gündeme getirmiştir. Gazetecilik etiği açısından, Kant'ın ödev ahlakı ve Mill'in faydacılık kuramı çalışma kapsamına alınmıştır. Çalışmadaki amaç basında etik kodların gerekliliğini iki önemli düşünürün etik görüşleri bağlamında temellendirmektir. Kant eylemlerimizde öznel ilke olarak seçeceğimizin herkes için geçerli olması üzerinde durmakta, yasa gibi kabul edebileceğimiz bu ilkenin eylemlerimize karar vermede belirleyici olması gerektiğini belirtmektedir. Mill ise eylemin değerini yarar kavramıyla açıklamaktadır. Mill toplumsal mutluluğu sağlamanın ahlaki eylemlerdeki temel ilke olduğunu ifade etmektedir. Her iki yaklaşım da eylemlerin değerini belirlemede ilkeler üzerinde durmaktadır. Etik kodların gerekliliği konusunda ortak bir kanı bulunmaktadır. Her durumun tekliğinde değerlendirilmesi gereği, yine de önceden belirlenmiş yol gösterici ilkeleri gerekli kılmaktadır. Etik kodun belirlenmesi gerekliliği, uluslararası düzeyde egemen güçlerin çıkarlarını meşrulaştıran bir zemin yaratılması amacıyla da kullanılabilmekte ve etik olmayan davranış kabul edilebilir hale gelebilmektedir. Etik kodlar, 'Yeni Dünya Düzeni'nde küresel etkiyle, etik sorunları çözme maskesi altında kendi egemenliklerini sürdürmek isteyen güçlerin kullandıkları bir araç olma tehlikesini de barındırmaktadır. Bu çalışmada, basında etik kodların gerekliliği iki düşünürün etik görüşleri bağlamında temellendirilmiştir. Etik kodların gazeteciler için rehber olacağı ve her etik durumun tekliğinde değerlendirilmesinde gazetecinin özgür iradesinin belirleyici olacağı ortaya konulmuştur. Çalışmada veri toplama tekniği olarak kaynak tarama yöntemi kullanılmıştır.

Anahtar Kelimeler: Basın, etik, küreselleşme, ödev ahlakı, faydacılık

\section{Giriş}

Etik, eylemlerin sorumluluk ve erdem bağlamında iyi ve kötü olarak değerlendirildiği, eylemin değerliliğinin temele alınan ilkelere göre tespit edildiği bir alandır. Etik alanda belirlenen etik kodlar, eylem öncesinde karar verilebilmesi ve sonrasında değerlilik ve doğruluk açısından bir değerlendirme yapılabilmesi için başvurulan ilkeler bütünüdür. Etik kodlara uygun davranılması yasal yaptırım gibi bir zorunlulukla değil, vicdani gereklilikle ve toplumsal kurallar bağlamında belirlenen gereklilikle işlemektedir.

Medyanın kamuoyunun oluşumuna katkısı ve denetleme işlevi, medyanın toplumsal sistem içindeki konumunun siyasi ve ekonomik güç odaklarına bağımlı hale gelmesi ve medyanın dönüşümü ile işlevsiz hale gelmeye başlamıştır. Gazetecilerin çalıştıkları kurumun çıkarları doğrultusunda haber yapmak zorunda bırakılmaları sonucu, basın etiği dışına çıkan durumlarla karşılaşmaları da bu süreçte etkili olmuştur. Ortaya çıkan etik sorunların çözümü için, uyulması gereken etik kodların belirlenmesi üzerinde durulmaktadır. Her durumun çözümüne karșılık gelecek etik bir kod bulunamaması karar alma sürecinde bir seçimi zorunlu kıldığından bireyin özgür iradesi devreye girmektedir. $\mathrm{Bu}$ nedenle etik sorunların çözümünde etik kodların belirlenmesi gerekliliği, bu kodların belirlenmesinde öznel bir ilkenin mi yoksa çoğunluğun yararına olanın $m ı$ temele alınacağı konusunda farklı görüşleri ortaya çıkarmıştır.

Ahlak öğretilerindeki ayrılıklar, iyi-kötü kavramlarının tanımlanmasındaki farkl11ıktan kaynaklanmaktadır. Bu öğretiler bireyci ahlak, toplumcu ahlak, Sofist ahlak anlayışı, ödev ahlakı ve yararcı ahlaktır (Özgen, 2006: 30). Bu çalışmada Kant'ın ödev ahlakı ve Mill'in faydacılık kuramı çalışma kapsamına alınmıştır. Kant genel bir yasa olması istenebilecek öznel ilkeye göre eylemde bulunmak gerektiği üzerinde dururken, özgürlüğü başka nedenlerin etkisinden bağımsız olarak karar verebilme olarak tanımlamaktadır. İyiyi yararlı olanla bir tutan Mill ise eylemin değerini yarar kavramıyla açıklamaktadır. Mill, mutluluk veren eylemleri değerli kabul etmektedir. 
Gazetecilerin haber üretim sürecinde karar verme aşamalarında, rehber olacak etik kodların belirlenmesi gerekmektedir. Toplumsal yapının dinamiklerinin de etik kodlar üzerinde etkisi bulunmaktadır. $\mathrm{Bu}$ durum küresel ölçekte etik kodlar belirlenmesi konusunu gündeme getirmektedir. Küresel etkiyle belirlenen etik kodların, uluslararası medya kuruluşlarının egemenliklerini yeniden üretmelerinin aracı haline gelmesi durumu, etik kodların belirlenmesi ve uygulanması aşamalarını daha da önemli hale getirmektedir.

\section{Etik Kavramı}

Ahlak felsefesi olarak bilinen etik, ödev, yükümlülük, sorumluluk, gereklilik, erdem gibi kavramları analiz eden, doğruluk ve yanlışlıkla, iyi ve kötüyle ilgili ahlaki yargıları ele alan, ahlaki eylemin doğasını soruşturan felsefenin dalı olarak tanımlanmaktadır (Cevizci, 1999: 18). Etik, ahlak üzerine derinliğine düşünmek, felsefe yapmaktır (Sökmen ve Tarakçığlu, 2011: 23). İlke ise ahlak alanında, eylemde temele alınan pratik kural, eylemi belirleyen, eylemin kendisinin sonucu olduğu norma karş1lık gelmektedir (Cevizci, 1999: 459).

Etik düşüncedeki amaç, ortak ahlaki başlangıç noktalarını temele alarak, ahlaki ilkeler üzerinde en yüksek oydaşma içinde olmayı sağlamaktır. Ahlaki kuralların, eylem başlamadan önce referans olarak ve eylemden sonra ise değerlendirme standardı olarak işlemesi gerekmektedir (Evers, 2010: 49-50).

Etik alanda, olması gereken belirlenerek, buna ulaşılması için yapılması gerekenler sıralanmakta ve yapılanların doğru ve değerli olup olmadığı tartışılmaktadır. Söylem ve eylemleri etiğe uygunlukları açısından değerlendirebilmek için de kodlar belirlemek gerekmektedir. Bu konuda düşünce birliğinin olması, kodların uygulanabilir olmasını ve meşru görülmesini sağlamaktadır. Etik kodların eylem öncesinde referans noktası olarak alınması, istenmeyen, tartışmalı durumların ortaya çıkmasını engellemektedir. Her söylem ve eylemin ortaya çıkış koşullarının farklı olması, her durumun tekliğinde değerlendirilmesi gerekliliğini zorunlu kıldığından, etik alanda belirlenen kodlar her durumu tam olarak karşılamasa da yol gösterici olmaktadır. 'İyi'nin ne olması gerektiği tanımlanırken, sınırlarının çizilmesinde çelişkilerle karşılaş1labilmektedir. Her iyi eylemin, doğru olduğu ve değerli olduğu iddia edilemeyeceğinden etik kodların belirlenmesi pek çok unsurun dikkate alınmasını gerektirmektedir. Hukuki olarak dayanak ve çözüm bulunamayan konularda etik kodlara başvurulabilmektedir.

Etik kodlar her durumda hukuk kuralları gibi kesin yargılarla bir karara varılmasını sağlayamamaktadır. Her eylem ya da söylem farklı dinamikleri barındırdığından, benzer bir olaydaki karar yetersiz kalabilmekte ve karar verecek bireyi yanlış yönlendirebilmektedir. Birey eylemin doğru ve değerli olması açısından bir değerlendirme yaptığında, eylemin aynı zamanda doğru ve değerli olmadığı durumlarla da karşılaşabilmektedir. Bu şartlarda doğru eylemin değerli olmaması ya da değerli eylemin doğru olmaması sonucuyla karşılaştı̆̆ında, doğru ya da değerli olması arasında bir seçim yapmak durumunda da kalabilmektedir. Bu nedenle etik kodlar her durum için hazır bir çözüm sunmamakta, yol gösterici olmakta ve her eylemin kendi dinamikleri bağlamında değerlendirilerek bir karara varılmasını sağlamaktadır.

Etik söz konusu olduğunda meslek etiği de üzerinde durulan önemli bir konu olmaktadır. Karşılaşılan farklı durumlarda meslek çalışanlarının karar vermelerinde yol gösterici ilkelere gerek duyulması, etik kodların belirlenmesinde etkili olmuştur. Basının kamuoyunun oluşumuna katkısı bağlamında toplum üzerinde etkisinin olması, basın çalışanlarının meslek etiğine uygun davranmaları için yol gösterici etik kodların belirlenmesini gerekli kılmıştır.

\section{Basında Etik}

Medya her toplumda bir güç merkezi olduğundan, bu gücün kötüye kullanılması sonucunda sorunların ortaya çıkması ve bu duruma toplumda tepki gösterilmesi basın etiği gereksinimini ortaya çıkarmıştır (Tepe, 2000: 121-122). 
Medya toplumda dördüncü güç olarak etkin ve yönlendirici olabilmektedir. Medyanın hareket noktası da her zaman, sınırları tam olarak çizilememiş, 'kamu yararı' ilkesi olmamaktadır. Medyanın siyaset ve ekonomi eksenindeki konumu, teknolojinin medya alanını dönüşüme uğratması medyanın işlevinin sorgulanması sonucunu doğururken, medyanın işlevlerinin neler olması gerektiği, gazetecilerin davranışlarının hangi ölçütlere göre belirlenmesi gerektiği basın etiğini gündeme getirmiştir. Medya endüstrisi ve teknoloji de bu sürece hız kazandırmıştır. Medya kuruluşlarının birleşmeleri ve medya sahiplerinin medyanın dışındaki sektörlerde de etkin olmalarıyla yatay, dikey ve çapraz tekelleşmeler görülmüştür. Bu durum verilen haberlerde medya kuruluşlarının ekonomik çıkarlarına ters düşecek bilgilerin yansıtılmaması sonucunu doğurmuştur. İnternet gazeteciliğinin gelişmesiyle bilginin hızlı yayılması ve doğruluğunun sınanmadan haber olarak verilmesi etik sorunların artmasına neden olmuştur.

Yeni teknolojiler geleneksel çalışma koşullarını değiştirmiştir. Haber dünyasının sanayileşmesi gazetecilerin etkinliğini azalttı̆̆ ve çabuk verim beklediği için, gazeteciler sorumluluk ve ahlak sorunlarıyla daha çok ilgilenmeye başlamışlardır (Ramonet, 2000: 61). Artık sadece gazeteci ve program yapımcılarının meslek etiği değil, herkesin etik sorunlarla karşılaştığı bir haber ve enformasyon endüstrisi yaratılmıştır (Evers, 2010: 59).

Teknoloji haberin toplanması, haber üretim süreci ve haberin dağıtımı aşamalarında dönüşüme yol açtığından, geleneksel çalışma koşullarındakinden farklı etik sorunlarla karşılaşılması, bu sorunları çözmek konusunda yetersiz kalınmasına neden olmuştur. Teknolojinin hızı ve bireylerin sosyal medya sayesinde etkileşimin bir parçası olmaları karşısında, medya alanı mesleki etik kodların belirlenmesi ve özellikle de uygulanması aşamasında hazırlıksız bir konumda bulunmaktadır. Etik sorunlarla karşılaşıldığında, var olan etik kodların uygulanabilirliği, gazetecinin bireysel tavrı ve toplumsal yaptırım önem kazanmaktadır.

Etik ile ilgili tartışmalardan kaçınılamamaktadır, çünkü medyada yasaların dışına çıkmadan da çarpıtma, peşin hüküm, propaganda, cinsiyetçilik, ırkçılık, manevi şahsiyete saldırı, özel hayata müdahale gibi çeşitli yollarla suç işlenebilmektedir (Belsey ve Chadwick, 1998: 22).

Medyada haberin içeriği yasal olarak suç içeren unsurları barındırmasa bile, haberde kullanılan dil ve kullanılan sözcükler, okurun haberi belirli bir bakış açısıyla değerlendirmesine neden olacak biçimde kurgulanabilmektedir. Haberde taraf dengesinin sağlanmaması, önyargılı ifadelerin yer alması, haber içeriğinin oluşturulmasında etik unsurların dikkate alınmamasından kaynaklanmaktadır.

Bir davranış kodunun sınırları çok iyi çizilmiş bile olsa, gazeteci etik çelişkilerle karşılaşabilmekte ve bir seçim yapmak durumunda kalabilmektedir. Belirlenen kodlar her durumu karşılayamamaktadır. Kodun etik olmayan davranışı önlemeye mi yönelik olduğu yoksa etik davranışın geliştirilmesini mi sağladığı konusu da sorun oluşturmaktadır. "Yalan söyleme!" ile "Gerçeği söyle!” aynı şey demek değildir (Belsey ve Chadwick, 1998: 24).

Etik olarak belirlenen kodun davranışı önlemeye yönelik olması tercih edilmekle birlikte, her durum için önleyici bir kod bulunamamaktadır. Her durumun özelinde gerçekleştiği koşullar öngörülememektedir. $\mathrm{Bu}$ nedenle her durum tekliğinde değerlendirilerek, etik davranışın geliştirilmesi için yeni etik kodların belirlenmesi gerekmektedir.

Medya etiği konusunda üç sorun bulunmaktadır. Birincisi etik kurama dayalı ilkelerin gerekliliği, ikincisi bu ilkelerin gazetecilik pratiğindeki sorunlara nasıl uygulanabileceği, üçüncüsü bu ilkelerin uygulanmasının medyada kaliteye nasıl yardımcı olacağıdır (Belsey ve Chadwick, 2002: 439).

İlk aşamada etik kurama dayalı kodların belirlenmesi, bu kodlar üzerinde uzlaşmanın sağlanması ve bu kodların her durum özelinde uygulanamaması halinde de 'ortak iyi' anlayışının gözetilerek karara varılması gerekmektedir. Gazetecilik pratiğindeki sorunlara uygulanmasında ise 
gazetecinin etik kodlara uygun davranmak konusundaki özgür iradesi ve bilinci devreye girmektedir. Medyadaki mülkiyet yapısı, yayın politikası bazı durumlarda gazetecinin etik kodlara uygun davranmasında engelleyici bir unsur olabilmektedir. Etik kodlara uygun davranmanın gazeteciler tarafından içselleştirilmesi, uygulamadaki sorunları azaltabilecek ve medyada kalitenin artmasını sağlayacaktır.

Gazetecilik etiğine ilişkin olarak iki farklı yaklaşım vardır. Bunlar Kant'ın deontolojisi ve faydacıların teleolojisidir. İlkinde her durum için geçerli olabilecek normların geliştirilmesi, ikincisinde her özgül durumda sonuçların ne olacağına tartarak karar verilmesi söz konusudur (İnal, 2010: 31).

\subsection{Immanuel Kant'ın Ödev Ahlakı}

Kant'ın ödev ahlakında isteme, özgürlük ve ödev kavramları önemlidir. İstemenin öznel ilkesi olarak belirttiği maksim kavramı da Kant'ın ahlak anlayışında davranışlara yön veren belirleyici ilkedir. Kant'a göre maksim kavramı, herkes için geçerli olması gereken genel bir yasadır.

Kant, eylem alanında her akıl sahibi varlık için geçerli olabilecek nitelikte olan ilkelerin olduğunu ortaya koyma çabasındadır. Bu nedenle, aklı ve arzulama yetisi olan bir varlık olarak insan istemesinin belirlenme olanaklarını ve sorunlarını araştırmaktadır (Kuçuradi, 1999: 62).

Kant istemeyi, akıl sahibi olmaları bakımından, canlı varlıkların bir tür nedenselliği olarak tanımlarken, özgürlüğü bu nedenselliğin, onu belirleyen yabancı nedenlerden bağımsız olarak etkili olabilme özelliği olarak ifade etmektedir (Kant, 1995: 64). İsteme kavramını akılla ilişkilendiren Kant, özgürlüğü bağımsız karar verebilme, isteme olarak açıklamaktadır. Başka nedenlerin etkisiyle istemeyi özgür bir isteme olarak tanımlamamaktadır.

Kant, istemenin öznel ilkesini 'maksim' olarak adlandırmaktadır (Kant, 1995: 16). Kesin buyruğun tek olduğunu belirterek, kesin buyruğu "ancak, aynı zamanda genel bir yasa olmasını isteyebileceğin maksime göre eylemde bulun" ş̧eklinde ifade etmektedir (Kant, 1995: 38). Kant'1n ödev ahlakında kesin buyruk, kategorik imperatif olarak da adlandırılmaktadır. Kant eylemlerimizde öznel ilke olarak seçeceğimizin herkes için geçerli olması üzerinde durmakta, yasa gibi kabul edebileceğimiz bu ilkenin eylemlerimize karar vermede belirleyici olması gerektiğini belirtmektedir.

İsteme başka türlü de karar verebildiğinden, zorunlu olarak ahlak yasasına uymak zorunda değildir. Burada bir zorunluluk değil, gereklilik söz konusudur (Akarsu, 1998: 43). Kant isteme konusunda özgürlüğü, başka nedenlerin etkisinden bağımsız olarak karar verebilme olarak tanımladığından, ahlak yasasına uymayı gereklilik kavramıyla açıklamaktadır. Eylemin değerini de ödeve uygunluğuna göre belirlemektedir.

Kant iyi istemeyi belirlemek için 'ödev' kavramına yönelmektedir. Bir eylem ödev olduğu için yapılıyorsa, ahlakça bir değeri var demektir (Akarsu, 1998: 42). Ödev kavramı nesnel olarak eylemin yasaya uygunluğunu istemektedir. Öznel olarak, yani maksimleri açısından ise yasaya sayg1 istemektedir. Ödeve uygun eylemde bulunmak ile ödevden dolayı yani yasaya saygıdan dolayı eylemde bulunmak bilinci arasındaki fark da buna dayanmaktadır (Kant, 1999: 89). Ödevden dolayı yapılan eylem de ahlaksal değerini, onu yapmaya karar verdirten maksimde bulmaktadır (Kant, 1995: 15).

Ödevden dolayı yapılan eylemde, yapan bakımından rastlantısallık değil, gereklilik bulunmaktadır. Çünkü eylemini belirleyen kesin buyruk olmaktadır. Eylemin hedefi de, ilişkide bulunduğu insanın insan olarak değerinin zedelenmemesidir (Kuçuradi, 1998:65).

Kant ödevden dolayı ve korkudan dolayı sözünü yerine getirmenin farklı olduğunu açıklamaktadır. İlkinde, eylem kavramının kendisi bile yasa içermektedir. İkincisinde ise eylemin 
etkilerini başka bir yerde aramak gerekmektedir (Kant, 1995: 18). Kant ödevden dolay1 yapılan davranışın yasa gereği yapıldığı için değeri olduğunu belirtmektedir. Yarar için yapılan eylemin etkileri başka bir yerde aranması gerektiğinden Kant'a göre değeri kendi içinde değildir.

Eylemde bulunurken kişinin ana amacı kendine ve başkasına insan olarak muamele etmek olduğunda, yani kendini ve başkasını sırf araç olarak değil, amaç olarak gördüğünde eylemi ahlaksal bir değer taşımaktadır (Kuçuradi, 1999: 64). 'Kendi başına da gelir' korkusuyla bir durumda bir insan hakkını koruyan ödeve uygun davranmış olmaktadır. İnsan olma bilinciyle koruyan ise ödevden dolayı o durumda bir insanın hakkını korumuş olmaktadır (Kuçuradi, 2006: 4).

Kant'ta 'iyi' saf pratik aklın, kesin buyruğun belirlediği isteme olmaktadır (Kuçuradi, 1998: 85). Kant'a göre 'iyi'nin iki türü vardır. Birincisinde, bir şey başka bir değerli olanı etkilediğinden iyidir. Bir ereğe ulaşmada araç olduğundan 'yararlı' olanla ilgilidir, değeri kendi içinde değildir. İkincisinde ise bir şeyin değeri kendi içindedir, 'kendinde iyi' dir. Kant kendi başına değer olarak da iyi istemeyi göstermektedir. İyi istemeyi de iyi niyet, iyi eylemi istemek ve iyi duruma ulaşmayı istemek ile karıştırmamak gerekmektedir. İyi isteme iyi eylemek için içten ve kararlı olarak hazır olmaktır. Eylemin ahlaksal değeri de ortaya koyduğu başarısında, sonucunda değil; eylemin arkasındaki düşünüştedir (Akarsu, 1998: 42). Kant iyi istemedeki belirleyici iyi eylemeye hazır olma durumunu, her durumda geçerli olan ve başka bir şeye bağlı olmayan koşulsuz buyruk olarak görmektedir.

İnsan istemesinde ahlak yasası ancak buyruk biçiminde kendini dile getirir. Doğa yasaları buyruk olamaz, ama pratik yasalar buyruktur. Kant'ta buyruklar da koşullu ve koşulsuz olarak ayrılmaktadır. Koşullu buyruklar, bir koşul altında geçerlidirler, burada istemenin belirli bir amacı vardır. Koşulsuz buyruk her durumda geçerlidir ve başka bir ereğe bağlı değildir. Ahlak yasası da böyle bir koşulsuz buyruktur (Akarsu, 1998: 43-44).

Kant'taki pratik buyruk, "eylemde bulunurken, kendimizi de başkasını da, eğilimlerimiziçıkarlarımızı gerçekleştirmek için bir araç olarak görmemeyi; başkasına yaptığımızı insan olmanın bilinciyle ve onun için yapmamızı bize buyuran bir buyruktur." (Kuçuradi, 1997: 3).

Kant'ın ödev ahlakındaki temel ilke, yarar kavramını dışlaması ve istemeyi araçsallıktan çıarıp, insan olmanın bilinciyle iyi olanı istemeyi bir amaç, yasa gibi görmesidir. Bu yasanın da herkes için geçerli olması gerektiğini vurgulamaktadır. Medyada da etik kodların bu araçsallık düşüncesinin yerine ödev bilinciyle uygulanması ve yasa olarak kabul edilmesi, pratikte karşılaşılan sorunların ve çalışanların hata yapma olasılıklarının azalmasını sağlayacaktır.

\subsection{John Stuart Mill ve Faydacilık}

Faydacıl1k, "genel iktisadi bir öğreti, bir siyaset felsefesi ve toplum teorisi olarak iyinin mutluluk ya da hazza ve dolayısıyla da doğruya eşit olduğu görüşü”dür (Cevizci, 1999: 917).

J. S. Mill'e göre bir düşüncenin doğruluğu onun yararlılığının bir parçasıdır (Mill, 2015: 34). Mill, 'iyi'yi yararlı olanla bir tutmaktadır. İnsan istencinin konusu haz ile acıdır. Haz ve acı insan eylemlerinin değerliliğinin ölçüsü olmaktadır. Mill'e göre eylemlerimiz mutluluğu sağladıkları ölçüde doğru, mutluluğun tersine yol açtıkları ölçüde doğru değildirler (Gökberk, 1996: 475-476). Mill, Kant’ta olduğu gibi yarar kavramını dışlamamakta ve eylemin değerini yarar kavramıyla açıklamaktadır. Mill, haz ve mutluluk veren eylemleri değerli kabul etmektedir.

Mill toplumsal mutlulukla bireysel mutluluk arasında bir koşutluğun bulunduğunu belirtmekte ve toplumsal mutluluğu sağlamak için çalışmanın ahlaki eylemlerdeki temel ilke olduğunu ifade etmektedir (Özgen, 2006: 45). Mill, bireye ya da topluma belli bir zarar gelmesi ya da belli bir zarar gelme tehlikesi bulunması halinde, bu durumun özgürlük alanından çıktığını, etik ve yasanın alanına girdiğini ifade etmektedir (Mill, 2015: 114). Mill, bireyin kendisinden başka hiç 
kimsenin çıkarlarını ilgilendirmediği sürece, topluma karşı kendi edimlerinden dolayı sorumlu olmadığını belirtmektedir (Mill, 2015: 130).

Mill toplumsal mutluluğu sağlamanın ahlaki eylemlerdeki temel ilke olduğunu ifade etmektedir. Fakat bireysel mutluluk ve toplumsal mutluluğun çatıştıkları noktada, toplumsal mutluluk için eylemde bulunmanın bireysel mutluluğu sağlamadığı sonucuyla karşılaşıldığında, yarar kavramı birey açısından çok anlamlı olmamaktadır. Çoğunluğun yararı için yapılan eylemin her zaman doğru ve değerli olduğu da iddia edilememektedir. Azınlığın yararının gözetilmemesi, yararın nicelikselliğine bakılarak eylemin doğru olarak nitelendirilmesi, etik kodların her durumda uygulanabilir olmasını güçleştirmektedir.

Faydacılara göre, davranışın doğru ya da yanlış olduğunu belirlerken bakılacak ilke, en çok sayıda kişinin iyiliğini amaçlamış olmasıdır. Mill, gazetecilik etiği açısından ifade özgürlüğünde, her düşüncenin dile getirilmesinin yol açacağı fayda açısından değerlendirilmesi gerektiği üzerinde durmaktadır. Mill'e göre, her düşüncenin içinde bir nebze hakikat bulunabilme olasıllğ 1 nedeniyle sınırsız bir ifade özgürlüğü gereklidir (İnal, 2010: 40-41).

Mill, düşünce özgürlüğü ile düşündüğünü söyleme özgürlüğünün, insanın düşünsel mutluluğu için zorunlu olduğunu dört nedene dayandırmaktadır. Birincisi, bir düşüncenin susturulmak zorunda bırakılsa bile doğru olabileceğidir. İkincisi, susturulan düşünce yanlış bile olsa, içinde hakikat bulunma olasılığı vardır. Üçüncüsü, tartışılmaz sayılan düşünce doğru bile olsa, o düşünceye, geçerli nedenleri pek az anlaşılıp hissedilerek, bir önyargı tarzında inanılabilmektedir. Dördüncüsü ise, asıl kuramın kendi anlamının yaşamsal etkisinden yoksun olmak tehlikesine düşeceğidir (Mill, 2015: 74).

Mill'in her düşüncenin içinde bir nebze hakikat bulunabilme olasıllı̆̆ nedeniyle sınırsız bir ifade özgürlüğünü savunması basın alanında önemlidir. Medyada tüm görüşlere yer verilmesi taraf dengesinin korunması açısından da değerlidir. Medyada bazı söylemlerin yansıtılması, diğerlerinin sansüre uğraması, medyanın haber verme ve bilgilendirme işlevlerini tam olarak yerine getirmediğini göstermektedir. Bazı medya kuruluşları, taraflı bir değerlendirme yaparak söylemleri aktarmakta ve toplum üzerinde yönlendirici olmaya çalışmaktadır. Bu şekilde okurların doğru haber alma hakkını engelleyerek basın etiğine aykırı davranmaktadırlar.

Mill'e göre, bütün insanlar aynı düşüncede olduklarında ve yalnızca bir kişi karşı düşüncede olduğunda, bir kişinin elinde güç olduğunda insanları susturmaya hakkı yoksa, insanların da bu birini susturmaya hakları bulunmamaktadır. Bir düşüncenin susturulmasındaki asıl kötülük, o düşüncenin yandaşlarından da fazla olarak, söz konusu düşünceye yandaş olmayanlara karşı bir soygunculuk olmasıdır. Düşünce eğer doğru ise, insanlar yanlış olanı doğru olanla değiştirmek imkanından yoksun bırakılırlar, eğer yanlış ise, onlar, aynı derecede büyük bir yararı elden kaçırmış olurlar (Mill, 2015: 25-26). Mill'in düşüncelerin özgürce ifade edilmesi konusundaki bu görüşleri, basın özgürlüğü bağlamında, haberde taraf dengesinin sağlanmas1 açısından önemli olmaktadır.

\section{Etik Kod}

Etik kod, hukuk alanının dışında kalan, gereklilik içeren, eylemde bulunurken rehber olan ilkeler bütünü olarak tanımlanabilmektedir. Etik kodlara uygun davranmak bireysel bir sorumluluğu da barındırmaktadır. Her durumda verili olan ilkelerden yola çıkarak olayın özgünlüğüne bağlı olarak karar vermek gerekmektedir. $\mathrm{Bu}$ kodların belirlenmesi için de uluslararası toplantılar yapılmış ve kararlar alınmıştır.

Avrupa Konseyi Parlamenterler Meclisi 'Gazetecilik Etiği’ ile ilgili olarak 1003 say1lı Kararı ve 1215 sayılı Tavsiyeyi 1 Temmuz 1993'de oybirliği ile kabul etmiştir. Bu metinler 'Avrupa Gazetecilik Deontolojisi Kodları' olarak bilinmektedir (Encabo, 2002: 443). 
“1993 yılı Basın Konseyi Çalışma Raporu'nda yayımlanan, Avrupa Konseyi Parlamenter Meclisi "Çözüm Tasarıları" başlığı altında belirlenen bazı kurallar şunlardır:

Haberler ve Yorumlar

1- Günümüzde, demokratik yaşamın çok önemli parçaları olan bilgilendirme ve iletişim kavramları konusunda, medyanın, topluma karşı ahlaki sorumlulukları vardır. $\mathrm{Bu}$ sorumlulukları da, kişisel davranışların, demokratik hayatın ve toplum bilincinin gelişmesinde önemli rol oynamaktadır.

2- Gazetecilik mesleği hak, yükümlülük, özgürlük ve sorumluluk gibi birçok kavramı içinde barındırır.

3- Gazeteciliğin temel ahlaki prensiplerinden biri de, haber ile yorum arasındaki belirgin ayırımın çizilmesi ve bunların karıştırılmasının önlenmesidir. Haber gerçeklere ve verilere dayalı bilgilendirmedir. Yorum ise yazanın, yayınlayanın veya medya şirketlerinin düşüncelerini, inançlarını, kişisel yargılarını içerir.

4- Haber yayını, gerçeklere dayandırılmalı ve doğruluğu ispatlanabilir olmalıdır. Haberin sunumunda ve betimlemelerde tarafsız davranılmalıdır. Haber başlıkları ve özetleri mümkün olduğunca doğruları ve eldeki verileri yansıtmalıdır.

5- Yorumlar, genel düşünceler veya günlük olaylar üzerine yapılabilir. Yorum subjektif olduğu için, doğruluğu üzerinde eleştiri yapılamaz. Bunun yerine, bizler yorumların dürüst ve ahlaklı olmasını sağlamalıyız.

6- Bazı kişi ve kuruluşlarla ilgili olaylar üzerinde yapılan yorumlar gerçekleri ve verileri çarpıtmamalı ve gizlememelidir.” (İlkiz ve Günaydın, 2006: 5).

Belirlenen bu kodlar, medyanın demokratik toplumdaki sorumluluğuna odaklanmakta, haberin doğruluğu ve yorumdan ayrılması gerekliliği üzerinde özellikle durmaktadır. Yorum haberi etik açıdan sorunlu hale getirmekte ve tarafsızlık idealini zayıflatmaktadır.

\subsection{Basında Etik Kod Belirlemenin Gerekliliği}

Bir davranış koduna sahip olmanın gerekçesi kaliteyi güvence altına almaktır (Belsey ve Chadwick, 1998: 28). Davranış kodları, gazetecilerin içinde bulundukları düzenleyici çerçevenin belki de en küçük parçasıdır (Harris, 1998: 89). Bir davranış koduna bağlılık, gazetecileri ortak amaçlar ve çıkarlar etrafında, kamuya karşı sorumluluklarını kabul eden profesyoneller olarak biraraya getirmektedir (Belsey ve Chadwick, 2002: 431).

Gazetecilerin içinde bulundukları düzenleyici çerçevede, davranış kodlarının yanı sıra yasalar, yayın kuruluşunun ilkeleri, toplumsal kurallar da bulunmaktadır. Yasaların ve yayın kuruluşunun politikası gazetecinin eylemleri üzerinde daha belirleyici ve baskın olmaktadır. Gazetecinin haber kaynağını açıklamaya zorlanamayacağı ifade edilse de, haberin neden olacağı sonuçlar itibariyle yasa karşısında gazetecinin haber kaynağını açıklaması istenebilmektedir. Bu da her durumda etik kodlara uygun davranılmasını zorlaştırmaktadır. Etik kodlara uygun davranılmadığında karşılaşılacak güçlü bir yaptırımın bulunmaması, sorumluluğu büyük ölçüde bireye yüklese de, etik kodlar nasıl davranılacağı konusunda seçim aşamasında yol gösterici olmaktadir.

Tepe (2000: 135) hazır normlarla değerlendirme yapmak konusunu şöyle açıklamaktadır:

“...etik her tek durumda geçerli olacak bazı değerlendirme ve davranış normları veremeyeceği gibi; belirli durumlarda nasıl davranılacağına ya da davranılmayacağına ilişkin normlar da getiremez. Olsa olsa bu türden hazır normlarla değerlendirme yapmanın ne olduğunu bize söyler; bu normların kendisinden türetildiği temeli bize gösterebilir." etmektedir:

Bauman da (1998: 41) iyi olanı yapmaya zorlayan dış gücün gerekliliğini şöyle ifade

“...insanların birçoğu, seçim yaparken ahlaki açıdan iyi olanı seçmez. Bu nedenle paradoksal bir şekilde, tam da yargılama ve seçme özgürlüğü, kişiyi 'kendi kurtuluşu' 
için, 'kendi iyiliği' için ya da 'kendi çıkarı' için iyi olanı yapmaya zorlayan bir dış gücü gerektirir."

Şahin (2011: 121) basın özgürlüğünün mesleki etik ilkelerin başında geldiğini şu sözlerle ifade etmektedir:

\begin{abstract}
"Basın ve ifade özgürlüğünü savunmak mesleki etik ilkelerinin başında yer alır. Bunu başka birkaç yerde 'doğruları doğru biçimde söylemek' yükümlülüğü olarak özetledim. Gazeteci olarak yalnız ve yalnız 'Hakikat'in peşinde olacaksınız. Tek gerçek patronunuzun-hayır, okurlar değil- doğrular olduğuna inanacaksınız!"
\end{abstract}

Etik kodların gerekliliği konusunda ortak bir kanı ve uzlaşma bulunmaktadır. Sorun kodların belirlenmesi ve uygulanması aşamasında ortaya çıkmaktadır. Kurala uygun davranışın doğru ve değerli olduğu konusu da muğlak olduğundan, kurallar göz ardı edilmeden bireysel olarak vicdani bir karar verilmesi çözüme katkı sağlamakta, etik kodlar da bu süreçte rehber olduğundan gerekli olmaktadır. Etik kodların belirlenmesi aşamasında, kodun yapılması ve yapılmaması gerekenleri sıralaması dışında, etik kodların geliştirilmesi için sahip olması gereken farklı işlevler de dikkate alınmalıdır.

Bir davranış kodunun, gerektirimler ve yasaklamalar dışında, denetimsel ve eğitimsel işlevlere sahip olması gerekmektedir. Ayrıca mesleki idealleri ve yüce hedefleri vurgulayan ütopik bir işleve de sahip olması beklenmektedir (Belsey ve Chadwick, 2002: 432). Etik kodun sahip olması gereken işlevler denetim mekanizması olarak da görülebilmektedir.

\title{
3.2. Etik Kod Belirlemede Otoritenin Etkisizliği ve Etik Kodun Uygulanmasında Özgür İradenin Etkisi
}

Etik ilkeler belli bir otorite eliyle belirlenmemekte ve belirlenememektedir. Bilim ve etik alanlarındaki ilkelerin, insan aklının ve insan deneyimlerinin birbirlerini etkileme becerileri yoluyla keşfedilmesi gerekmektedir (Belsey ve Chadwick, 1998: 25).

Basının ve gazetecilerin çalışma ilkelerini oluşturmak için ortaya konulan ilkelerin yasalara dayanan cezai yaptırımlara bağlanmaları, o ülkede basının sıkıntıya girmesine neden olmaktadır. Ahlak her şeyden önce özgür iradenin seçeceği tutum ve davranış biçimlerinin varlığı ile ortaya çıkmaktadır (Özgen, 2006: 65). Kuçuradi (1998:15) kişinin yaşamında bir şeyi değeri bakımından değerlendirmenin bir bilgi problemi olduğu kadar, değerlendiren bakımından bir insan problemi olduğu üzerinde durmaktadır.

Etik kodlar, gazetecinin bireysel olarak karar vereceği durumlarla karşılaştığında yapması gerekenleri belirlediğinden, ayrica bir otorite tarafindan yasalar gibi ifade edilememektedir. Bireyin vereceği öznel kararı yargılayacak olan kendi vicdanı olmaktadır.

Basın ahlak ilkeleri, yasalar gibi zorlayıcı hükümlere dayanmadıklarından, gazetecinin özgür karar verebilmesi mesleki bir değer kazanmaktadır. Bu da Aristoteles'in irade özgürlüğüne verdiği önemi ortaya çıkarmaktadır (Özgen, 2006: 76). Yasa gibi zorlayıcı bir hüküm olmadan gazetecinin özgür bir şekilde karar verebilmesi, vicdani bir sorumluluğu hissetmesiyle de bağlantılı olmaktadır.

Etik değeri belirleyen ilke, baskı altında kalmadan özgür istemeyle 'iyi' olan davranışı yapmaya karar verebilmek olmaktadır. Bu düşünce Kant'ın ödev ahlakını temele almaktadır. Bu nedenle etik kodların belirlenmesinden çok bireysel davranış biçimlerinin daha etkili olduğunu savunanlar da bulunmaktadır. Erdoğan (2006: 9) etik konusunda moral kodlar yerine insanlar aras1 ilişkilere odaklanan Martin Buber'in görüşlerini şöyle aktarmaktadır:

"Martin Buber etik konusunu moral kodlar yerine insanlar arası ilişkide aramıştır. Ona göre, etiğin özü insanlar arası gerçek diyalogun olmasıdır. İnsanlar araç değildir, sonuçtur. Bizim etiksel sorumluluğumuz şeyleri kullanma ve insana değer vermedir; insanları kullanma ve şeylere değer verme değil. Buber'in etik anlayışında, insanlar 
birbiri üzerinde olumlu imajlar yaratma ve sürdürme ile uğraşmazlar; 'gerçek,' bireyin diğerleriyle şeffaf ilişkisinden çıkar gelir.'

Erdemli bir karakterin ortaya çıkması için, gazetecinin erdemli davranması ve kaliteye önem vermesi gerekmektedir. (Belsey ve Chadwick, 2002: 439). Etik kodlar özgür irade ile eylemde bulunacak bireylerin varlığıyla anlam kazanmaktadır.

\subsection{Toplumsal Yapının Etik Kodların Uygulanabilirliğine Katkısı}

Mesleki etik ilkelerin belirlenmesi, o ülkedeki toplumsal değer yargılarına dayanmaktadır. O ülkede yetişen gazeteci de, yetiştiği ve yaşadığı toplumun ürünü olduğundan, toplumun koşullarını göz ardı edememektedir (Özgen, 2006: 75).

Etik kodlar tarihsel süreç içerisinde toplumların etkisiyle şekillenmiş olduğundan, bireylerin üyesi oldukları toplumsal yapının değerleriyle hareket etmeleri olağan görülmekle birlikte, küreselleşme süreciyle etik kodlar da bir değişim dinamiğine sahip olmaktadır. Etik kodların belirlenmesinde daha evrensel bir yaklaşım da söz konusu olabilmektedir. Birey, küreselleşme süreciyle üyesi olduğu toplumsal yapının değer yargılarının etkisinde kalmayarak da karar verebilmektedir. Etik söz konusu olduğunda bazı durumlarda bireysel karar alma süreci, toplumsal sisteme bağl1lıktan daha önemli olabilmektedir.

Bir toplum üyelerinin ahlak ve sorumluluk duygusuna bağımlı olduğundan, medya profesyonellerinin böyle bir duyguya sahip olmamaları kalitenin eksik kalmasına neden olmaktadır. Hukuksal yasaklama ve kısıtlamalar da gazetecilerin bunlardan nasıl kaçacakları üzerinde yoğunlaşmalarına ve etik konulardan uzak durmalarına yol açmaktadır (Belsey ve Chadwick, 2002: 430).

Yasadışı sayılan şeyler etik dışı da sayılmaktadır, ancak bazen de gazeteciler yasal sonuçlarından korktukları için etik olan bir davranışı yapmamaktadırlar. Bir devlet sırrının dışarıya sızdırılması kamu yararına hizmet edecekken yasa gereği bunun yapılmaması örnek olarak verilebilmektedir (Harris, 1998: 90). Gazeteciler etik davranmak adına kamuoyunu bilgilendirmeye çalıştıklarında ise baskıyla karşılaşmaktadırlar.

Normların amacına uygun olarak bir işleve sahip olması için, felsefenin gösterdiği yol, norm üretirken hareket edilen öncülün, insanın yapısına uygun olmasıdır. Toplumsal grupların normlarının talepleri doğrultusunda gerçekleştirilecek eylemler, birbirleriyle çeliştiğinde, yapılacak en doğru şey, bu normları oldukları gibi veri olarak alıp ısrar etmek değildir. Bu durum çatışmayı önleyememektedir. Yapılacak şey, bu normlara dayanak olan insan hakkındaki öncüllerin sinanmasıdır. Felsefi-epistemolojik bir etkinlik olan bu sinama, belli bir görme gücü gerektirmektedir. $\mathrm{Bu}$ görme gücünün yokluğunda ise her toplumsal grubun kendi normlarını bask1 gücüyle egemen kılma girişimi ortaya çıkmaktadır (Kaygı, 2006: 47-48).

Ülkelerin sahip oldukları rejimler de, etik kodun gazeteciler tarafindan algılanışını etkilemektedir. Gazetecilerin toplumsal bask1, hukuksal yasaklama ve bireysel karar verme unsurları arasında yapacağı tercih, davranışının etik değerini belirlemektedir.

Kod, baskıcı rejimlerde mağdur durumdaki gazetecilere ahlaki destek vermeyi ve mesleki dayanışmayı teşvik etmeyi olanaklı kılarken, liberal rejimlerde daha çok halktan kişileri korumay1 sağlamaktadır (Harris, 1998: 86). Etik kodların farklı rejimlerdeki algılanışı, küresel ölçekte etik kodların belirlenmesi düşüncesini gündeme getirmiştir. Küreselleşmenin etkisiyle, bir taraftan ortak temelde bir insan etiğine ihtiyaç duyulması üzerinde durulurken, diğer taraftan etik tartışmalarda politik, ekonomik ve kültürel farklılıkların göz ardı edildiği de ifade edilmektedir.

\section{Küreselleşme Sürecinin Etik Kodlar Üzerindeki Etkisi}

Ekonominin, teknolojinin ve medyanın küreselleşmesinin getirdiği küresel sorunlara küresel çözümler üretilebilmesi amaciyla etiğin küreselleşmesinden söz edilmektedir. Etiğin 
küreselleşmesinden kastedilen de ulusların, çıkar gruplarının üzerinde uzlaşacağı etik değerler ve ilkeler olmaktadır. Ortak bir temelde insan etiğine ihtiyaç duyulmaktadır. Küresel etik olmadan yeni dünya düzeninin olamayacağı ifade edilmektedir (Küng, 2005: 2). Küresel etik, yeni dünya düzeninde eşitsizliklerin sürdürülmesinin aracı olarak değil, bu eşitsizliklerin ortadan kaldırılmasında etkili olabildiği ölçüde kalıcı ve değerli olabilecektir. Bu amaçla da dijital çağın gerekleri dikkate alınarak etik kodların düzenlenmesi gerekmektedir.

Gazetecilikte, özellikle de ulusal sınırları ve yasaları aşan internet gönderilerinin temsil ettiği yeni medya alanında, küresel etik hakkında daha fazla çalışmanın yapılması ve kodların dijital çağı yansitacak şekilde yeniden gözden geçirilmesi gerekmektedir (Meyer, 2011: 37). Ulusal sınırları ve yasaları aşan yeni medya alanında, demokratikliğin olması için enformasyon akışının tek taraflı değil, iki taraflı olması sağlanmalıdır.

Ulusal düzeyde geçerli olanlar uluslararası düzeyde de geçerli olmaktadır. Küresel düzeyde bilgi ve haber kalitesi ve akışı için işbirliği gerekmektedir. Haberleşme özgürlüğünün küresel boyutta güvence altına alınması için küresel haberleşme şebekelerinin ve bunlara demokratik olarak ulaşma hakkının bulunması zorunlu olmaktadır (Belsey ve Chadwick, 1998: 29).

Küresel düzeyde bilgi ve haber akışının sağlanması, haberleşme özgürlüğü ve demokratiklik olarak olumlu bir şekilde ifade edilse de, bilgi akışının dengesiz ve tek taraflı olması ve belirli güçlerce haber üretim sürecinin işletilmesi özgürlük ve demokratiklik kavramlarını zedelemektedir. Etik kodlar söz konusu olduğunda da küreselleşme süreciyle birlikte benzer bir etki yaratılmaya çalışılmaktadır.

Etik tartışmalarında değişik coğrafyalardaki politik, iktisadi ve kültürel farklılıklar göz ardı edilmekte ve tikel bir örneğe atıfla etik norm koyulma eğilimi güçlenmektedir (Adakl1, 2010: 9091).

Etik kodun belirlenmesi gerekliliği, uluslararası düzeyde egemen güçlerin çıkarlarını meşrulaştıran bir zemin yaratılması amacıyla da kullanılmaktadır. Etik alanında da küreselleşmenin etkisiyle tek tip bir kurallar çerçevesinin belirlenmesi, belirleyen gücün isteklerine göre şekil almaktadır. Bu sayede etik, etik olmayan davranışı kabul edilebilir hale getirmektedir. Evrensel olarak belirlenebilecek etik kodlar olduğu gibi, toplumların yapısını oluşturan farklı dinamiklerin etkisiyle dönüşüme uğrayacak kodlar da olabilmektedir.

Medya endüstrisinde var olan egemen güçler çalışanları biçimlendirmekte, meslek kurallarını ve uygulanma biçimlerini belirlemektedirler (Çaplı,2002: 212). Bazı Batı ülkelerinde medya için içsel ve dışsal özgürlük kavramları belirlenmiştir. Dışsal özgürlük basının devletten bağımsız olmasını, içsel özgürlük ise gazetecilerin gazete sahiplerinden bağımsız olmasını ifade etmektedir (Çapl1, 2002: 216).

Etik kodlar sadece küresel çıkar gruplarının ilgi odağı olmamaktadır. Medya alanında da hem küresel hem ulusal alanda çıkar grupları etik kodları kendi endüstrilerinin gereklerine göre şekillendirmek istemektedir. Etik, siyaset ve sermayenin etkisinde etik olmayan alana hizmet eden çelişkili bir yapıya dönüş̧ebilmektedir. Medya bu bağlamda ne içsel özgürlüğe ne de dışsal özgürlüğe sahip olmaktadır. Özgürlük ve etik kodlar sadece teorik olarak kabul edilmekte, pratikte işler olmamakta ve var olan eşitsiz yapıların üstünü örtmektedir.

Etik kodların uygulanabilir olduğu bir toplumsal yapının inşa edilememesi, etik kod kavramının içini boşaltmakta ve işlevsiz kurallar listesi olarak algılanmasına neden olmaktadır. Mutlu da (2005: 232-233) medya etiği konusunda içi boş ilkeler bütünü ifadesini şöyle açıklamaktadır:

“...medya etiği dediğimiz söylemsel yapı esasında içi boş kural ve ilkeler bütününden başka bir şey değildir. Ne var ki bu boşluk medyanın güncel ahval ve şeraitine denk düşecek uygulamalarla doldurulur; esas olarak da medyada ve medyanın konumlandığı

Turkish Studies - Social, 15(1) 
genel mekandaki iktidar ilişkilerince şekillendirilir. $\mathrm{Bu}$ süreçte kodları adlandıran kavramlar evrensel görünümleriyle tikel asimetrileri de gizlerler. Çünkü medya etiğinin ekseninde yer alan kavramlar, mesela 'nesnellik' kavramı tüm evrensel tınılarıyla medyadaki tikel çıkar ilişkilerini örten bir işlev görür."

Medyada etik kodların belirlenmesi çalışanlara rehberlik etmesi ve başvuru kaynağı olması açısından anlamlıdır. Sorun bu ilkelerin uygulanmamasından ve çıkar gruplarının hizmetinde şekil almasından kaynaklanmaktadır. Medya, siyaset, ekonomi ve küresel konjonktürden bağımsız bir yap1 değildir. Değişen mülkiyet yapısı hem kontrol sorununu gündeme getirmekte hem de etik sorunların çözümünde yapılması gerekenler konusunda medyanın taraflı etkisini pekiştirerek etik sorunlarda çıkmazlara neden olmaktadır.

Etik kuralların etkin olmaması, kurallara önem veriliyor izlenimi yaratılması, etik olmayan davranışların yapılmasını sağlayabilmektedir. Etik, etik olmayan davranışın gizlenmesi işlevini görebilmektedir (Sökmen ve Tarakçıŏlu, 2011: 93). Gazeteciler için belirlenmiş etik ilkelerden halkın yararlandığı ifade edilse bile, belirlenmiş bu kodlardan gazetecilerin ilişkide bulundukları kişiler ve halkın bir bölümü yarar sağlamaktadır (Uzun, 2009: 49).

Etik kodlar var olan eşitsiz yapıyı ortadan kaldıracağına, medyanın etkisiyle bu yapıyı güçlendirebilmektedir. Görünüşteki kurallara bağl1lık, temelde bir kuralsızlığı barındırarak, etik olmayan yapıyı kabul edilebilir ve olması gereken bir durum gibi yansitabilmektedir.

\section{Etik Kodu Belirleyecek Kurumun Sorumluluğu}

Basın ahlakında, etik ilkelerin belirlenmesi, bunu gerçekleştirecek kurumu önemli kılmaktadır. Bu önem de, basının, özgürlükçü, demokratik ve çoğulcu-parlamenter rejime dayalı ülkelerde yüklendiği toplumsal sorumluluktan kaynaklanmaktadır (Özgen, 2006: 68). Etik kodu belirleyecek kurum da, toplumsal sistemdeki yerine uygun olarak kodun içeriği üzerinde etkili olacağından belirlenen kod kurumun felsefesini ve kültürünü taşıyacaktır.

Kodun içeriği onu hazırlayan cemiyete bağlı olacaktır. Britanya'da kodlar sendika, yayıncılar birliği, hükümete bağlı bir komite ve hukuk heyeti tarafından oluşturulurken; Amerika Birleşik Devletleri'nde gazete editörleri ve radyo ve televizyon direktörleri tarafindan oluşturulmaktadır (Harris, 1998: 86).

Gazetecinin yükümlülüklerini dış müdahale olmadan belirleme düşüncesiyle, Uluslararası Gazeteciler Federasyonu 1954 yılında, Bordo Bildirgesi'nde onur kuralları ve yasasını benimsemiştir. 1971 yılında AET'ye üye ülkelerin gazeteci sendikaları Münih Bildirgesi altında bazı kuralları yeniden düzenlemiştir. Her iki bildirge de mesleki konularda gazetecilerin yalnızca meslektaşlarının otoritesini kabul edecekleri üzerinde durmaktadır (Tokgöz, 2003: 123-124). Farklı ülkelerde etik kodları belirleyenler de farklılaşmakta, kimisinde basın dışından kurumlar kimisinde ise basın çalışanları belirleyici olmaktadır. Türkiye'de ise bu alanda Basın Konseyi basın sorunlarını görüşmek üzere kurulmuştur.

1985 yılında basının sorunlarını konuşmak için bir araya gelen, basın özgürlüğü ve halkın gerçeklerden haberdar olma hakkını savunan gazetecilerin ortaya koyduğu bir fikirle Basın Konseyi, 6 Şubat 1988 tarihinde kurulmuştur (İnuğur, 1992: 506). Etik kodların belirlenmesinde meslek birliklerinin oluşturduğu bir kurumun sorumlu olması, çalışanlar üzerinde etik kodlara uygun davranmadıklarında bir yaptırım gücünün sağlanması ve çalışanların baskılara karşı korunması açısından önemlidir. Bu güç kuruma önemli bir sorumluluk yüklemekte ve siyasi iktidarlar ve medya mülkiyetine sahip olanlar karşısında meslek çalışanlarını koruyan bir konum almasina neden olmaktadır.

\section{Sonuç}

Etik alanın sınırları hukukun dışında kalan sorunlar olarak çizilmektedir. Etik doğru ve iyi olanı belirlemeye çalışan, ideal olana ulaşılması için yapılması gerekenleri ortaya koyan bir alandır. 
Etik alanda 'iyi' kavramı temelde yer alırken, eylemlerin 'doğru' ve 'değerli' olmaları da davranışın istenilir olmasını etkilemektedir. Her olayın tekliğinde değerlendirilmesi gerekliliği, çözüm için hazır bir formülü yetersiz kıldığından etik sorunların çözümü temel sorunsal olmaktadır.

Konu basın etiği olduğunda ise, siyaset, ekonomi, teknoloji, değişen mülkiyet yapısı gibi unsurlar etik sorunları çeşitlendirmekte ve çözüm üretilmesi güçleşmektedir. Medya denilen alan zamanla değişen koşullar altında artık dördüncü güç olarak gerilerde kalmamakta, ekonominin medya alanındaki belirleyiciliği ile kamuoyunun istenilen şekilde yönlendirilmesinde daha da belirgin bir rol üstlenmektedir. Ekonominin belirleyiciliğinin etkisi medyayı da diğer unsurlardan öncelikli bir konuma getirmiştir. Medyadaki sahiplik olgusu, tarafsızlık ve bağımsızlık kavramlarını ekonominin etkisinde zayıflatmaktadır. Bu nedenle basın etiği daha fazla üzerinde durulması gereken bir konu olmaktadır. Denetim mekanizmalarının işlemediği bir medya, toplumsal yarar adı altında müdahaleci ve yönlendirici bir işlevle etik olmayan bir durumu meşrulaştırabilme tehlikesini de taşımaktadır.

Medya alanındaki endüstrileşme süreci, haber üretimini standartlaştırırken, bu süreçte hata yapma olasılığını arttırdığını göz ardı etmektedir. Teknolojik hıza uyum sağlamaya çalışan yasal süreç yetersiz kalabilmekte, etik de bu hıza uyum sağlamanın ötesinde adeta süreci yavaşlatan bir unsur gibi algilanabilmektedir.

Basın etiği konusunda farklı yaklaşımlar bulunmaktadır. Kant, Ahlak Metafiziğinin Temellendirilmesi kitabında istemenin öznel ilkesi olan maksim kavramından söz etmekte ve bu ilkenin herkes için geçerli olması gerektiğini belirtmektedir. Özgürlüğü de bağımsız karar verebilme, isteme olarak açıklamaktadır. Mill ise en çok sayıda kişinin iyiliğini sağlamayı temele almaktadır. Etik söz konusu olduğunda nicel olana göre karar vermek her zaman doğru sonuçlara ulaştırmamaktadır, sonuçlar doğru bile olsa yapılan eylemin 'değerliliği' tartışma konusu olabilmektedir. Bu nedenle herkes için geçerli kabul edilecek öznel bir ilkeyi hareket noktası olarak almak, bireysel karar verebilmeyi özgürlük olarak tanımlamak etik alanda daha yol gösterici olmaktadir.

Etik kod belirlemenin gerekliliği konusunda ortak bir kanı oluşmuştur. Gerekçe olarak da niteliğin sağlanması dile getirilmektedir. Belirlenen etik kodların kamuya karşı sorumluluk sağladığı da ifade edilmektedir. Etik kodların belirlenmesinde ise bu kodların meslek çalışanları tarafından hazırlanmasının, müdahalenin olmamasının üzerinde durulmaktadır.

Etik kodların belirlenmesinde toplumsal etkiden söz edilmekle birlikte, evrensel olarak belirlenecek ilkeler üzerinde de durulmaktadır. Etik kod, bir toplumda medya çalışanları için sorumluluk duygusuyla hareket edip, özgür iradeleriyle karar almalarını sağlayan rehber olmakla birlikte, küresel alanda tahakkümlerini kurmak ve devam ettirmek isteyen güçlerin kullandıkları bir araç olma sakıncasını da taşımaktadır. Küresel düzeyde belirlenmiş ilkeler, tek taraflı enformasyon akışını doğallaştırmakta, tek otoritenin varlığını meşru kılmaktadır. Basının haberi tarafsız bir şekilde vermesi, küresel düzeyde belirlenmiş ilkelerin başında gelmektedir. Verilen haberde ulusal ve uluslararası alandaki çıkarların çatışması durumunda haberin hangi ölçütlere göre aktarılacağı konusunda bir netlik yoktur. Güçlü olanın enformasyonu aktarması daha hızlı ve etkili olduğundan, tek taraflı enformasyon akışı etik bir sorun olarak karşımıza çıkmaktadır.

Etik kodların bütünleyici olma işlevi, kendi amaçları için etik kodları kullanan güçlerin elinde kitleleri yönlendirmenin aracı haline dönüşmekte ve bunu üstü örtülü ve haklılaştıran bir şekilde uygulamaya geçirdiklerinden bu tehlikeli süreç görünmez bir şekilde işlemektedir. Medyadaki kurumların kendi mesleki etik kodlarını yaratmaları da bu sürecin devamı niteliğindedir. Medyada çalışılan kurumdan bağımsız olunması engellenirken, aynı zamanda kurum tarafından etik kodların yaratılarak çalışanların buna uymaları gerektiğinin belirtilmesi kendi içinde çelişkili bir yapının ortaya çıkmasına neden olmaktadır. Bu çelişkili yapı etik kodları fazlasıyla 
idealize ederek de basın özgürlüğ̈̈nü kısıtladığını gizlemektedir. Etik kodlar da etik alana hizmet etmekte işlevsiz, egemen güçlerin tahakkümlerini sağlamakta oldukça etkili unsurlar haline gelmektedir.

Etik kodlar, gazetecinin bireysel olarak karar vereceği durumlarla karşılaştığında yapması gerekenleri belirlediğinden, bireyin vereceği öznel kararı yargılayacak olan kendi vicdanı olmaktadır. Basın alanında etik kod gazeteciye karșılaștığı olaylarda karar alma sürecinde rehber olması bağlamında gereklidir. Bu gerekliliğin çıkar gruplarının aracı haline dönüşmemesi için herkes için geçerli kabul edilecek etik kodların belirlenmesi ve gazetecilerin karar alma sürecinde özgür olmas1 gerekmektedir.

\section{Kaynakça}

Adaklı, G. (2010). "Gazetecilik Etiğini Belirleyen Yapısal Unsurlar: Mülkiyet ve Kontrol Sorunu”. Televizyon Haberciliğinde Etik. B. Çaplı, H. Tuncel (ed.). Ankara: Fersa Matbaacılık, s.61-96.

Akarsu, B. (1998). Çağdaş Felsefe Kant'tan Günümüze Felsefe Akımları. 4.Baskı. İstanbul: İnkılap Kitabevi.

Bauman, Z. (1998). Postmodern Etik. A. Türker (Çev.). İstanbul: Ayrıntı Yayınları.

Belsey, A. ve Chadwick, R. (1998). "Medyada Etik ve Siyaset: Kalite Arayışı". N. Türkoğlu (Çev.). Medya ve Gazetecilikte Etik Sorunlar. A. Belsey ve R. Chadwick (Der.). İstanbul: Ayrınt1 Yayınları, s.13-29. https://doi.org/10.14527/9786052416204.11

Belsey, A. ve Chadwick, R. (2002). "Medyada Kalitenin Bir Aracı Olarak Etik". Medya, Kültür, Siyaset. S. İrvan (Der.). 2.Bask1. Ankara: Alp Yayınevi, s.423-441.

Cevizci, A. (1999). Felsefe Sözlüğü. 3. Baskı. İstanbul: Paradigma Yayınlar1.

Çapl1, B. (2002). Medya ve Etik. Ankara: İmge Kitabevi.

Encabo, M. N. (2002). "Gazetecilik Etiği ve Demokrasi”. Ü. H. Yolsal (Çev.). Medya, Kültür, Siyaset. S. İrvan (Der.). 2.Baskı. Ankara: Alp Yayınevi, s.443-464.

Erdoğan, İ. (2006). "Medya ve Etik: Eleştirel Bir Giriş". İletişim Kuram ve Araştırma Dergisi, Sayı 23, s.1-26. http://irfanerdogan.com/makalelerson/medyaetik2007.pdf Erişim tarihi: 14 Eylül 2019. https://doi.org/10.19145/guifd.90435

Evers, H. (2010). "Medya Etiği”. Televizyon Haberciliğinde Etik. B. Çaplı, H. Tuncel (ed.). Ankara: Fersa Matbaacilık, s.45-59.

Gökberk, M. (1996). Felsefe Tarihi. 8. Baskı. İstanbul: Remzi Kitabevi.

Harris, N. G. E. (1998). "Gazeteciler İçin Davranış Kodları". N. Türkoğlu (Çev.). Medya ve Gazetecilikte Etik Sorunlar. A. Belsey ve R. Chadwick (Der.). İstanbul: Ayrıntı Yayınları, s.85-101.

İlkiz, F. ve Günaydın, B. (2006) "Kisilik Hakları - Medyada Etik ve Yarg1 Kararları”. Küresel Iletişim Dergisi, $\quad$ Say1 $2, \quad$ s.1-15. $\quad$ http://globalmediatr.emu.edu.tr/guz2006/Hakemli_Yazilar/Fikret\%20Ilkiz_Baris\%20G\%C3\%BCnaydin.\%20 Kisilik\%20Haklari.\%20Onayli.pdf Erişim tarihi: 14 Eylül 2019.

İnal, A. (2010). "Tarihsel Gelişim İçinden Gazetecilik Etiğini Yeniden Düşünmek". Televizyon Haberciliğinde Etik. B. Çaplı, H. Tuncel (ed.). Ankara: Fersa Matbaacılık, s.27-44.

İnuğur, N. (1992). Türk Basın Tarihi. İstanbul: Gazeteciler Cemiyeti Yayınları. 
Kant, I. (1995). Ahlak Metafiziğinin Temellendirilmesi. İ. Kuçuradi (Çev.). 2. Baskı. Ankara: Türkiye Felsefe Kurumu Yayınları.

(1999). Pratik Aklın Eleştirisi. İ. Kuçuradi, Ü. Gökberk, F. Akatlı (Çev.). 3. Baskı. Ankara: Türkiye Felsefe Kurumu Yayınları.

Kayg1, A. (2006). "Kesin Buyruğu Doğru Anlamak”. Barışın Felsefesi 200. Ölüm Yılında Kant. İ. Kuçuradi (Haz.). Ankara: Türkiye Felsefe Kurumu Yayınları, s. 7-53.

Kuçuradi, İ. (1997). Uludağ Konuşmaları Özgürlük Ahlak Kültür Kavramlarl. 3. Bask1. Ankara: Türkiye Felsefe Kurumu Yayınları. (1998). Insan ve Değerleri. 2. Baskı. Ankara: Türkiye Felsefe Kurumu Yayınları. (1999). Etik. 3. Bask1. Ankara: Türkiye Felsefe Kurumu Yayınları.

(2006). “ “Altın Kural'a Karşı 'Kesin Buyruk”. Barışın Felsefesi 200. Ölüm Yılında Kant. İ. Kuçuradi (Haz.). Ankara: Türkiye Felsefe Kurumu Yayınları, s. 1-6.

Küng, H. (2005). "Global Ethic and Human Responsibilities". http://www.oneworlduv.com/wpcontent/uploads/2011/06/hkung_santaclara_univ_global_ethic_human_resp_2005.pdf Erişim tarihi: 14 Eylül 2019.

Meyer, E. L. (2011). "Media Codes of Ethics: The Difficulty of Defining Standards". https://www.cima.ned.org/wp-content/uploads/2015/01/CIMA-Codes-of-Ethics-11-03-

11_0.pdf Erişim tarihi: 14 Eylül 2019.

Mill, J. S. (2015). Özgürlük Üzerine. 4. Basım. İstanbul: Oda Yayınları.

Mutlu, E. (2005). "Saddam, İkiz Kuleler ve Global Medya Ahlakı". Globalleşme, Popüler Kültür ve Medya. D. B. Kejanlığlu ve A. Yıldız (haz.). Ankara: Ütopya Yayınevi, s. 218-258. https://doi.org/10.14527/9786050370201.12

Özgen, M. (2006). Gazetecinin Etik Kimliği. 3. Baskı. İstanbul: Set-Systems Yayıncılık.

Ramonet, I. (2000). Medyanın Zorbalı̆̆. A. Derman (Çev.). İstanbul: Om Yayınevi.

Sökmen, A. ve Tarakçığlu, S. (2011). Mesleki Etik. Ankara: Detay Yayıncılık.

Şahin, H. (2011). Can Çekişen Bir Meslek Üzerine Son Notlar. İstanbul: Say Yayınları.

Tepe, H. (2000). Etik ve Meslek Etikleri. Ankara: Türkiye Felsefe Kurumu Yayınları.

Tokgöz, O. (2003). Temel Gazetecilik. 5.Baskı. Ankara: İmge Kitabevi.

Uzun, R. (2009). İletişim Etiği. Ankara: Dipnot Yayınları. 